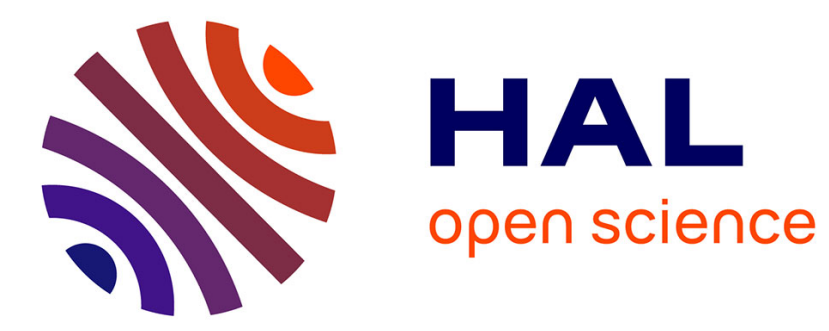

\title{
Desert roughness retrieval using CYGNSS GNSS-R data
}

D. Stilla, Mehrez Zribi, N. Pierdicca, N. Baghdadi, Mireille Huc

\section{To cite this version:}

D. Stilla, Mehrez Zribi, N. Pierdicca, N. Baghdadi, Mireille Huc. Desert roughness retrieval using CYGNSS GNSS-R data. Remote Sensing, 2020, 12 (4), pp.1-16. 10.3390/rs12040743 . hal-02610241

\section{HAL Id: hal-02610241 https://hal.inrae.fr/hal-02610241}

Submitted on 16 May 2020

HAL is a multi-disciplinary open access archive for the deposit and dissemination of scientific research documents, whether they are published or not. The documents may come from teaching and research institutions in France or abroad, or from public or private research centers.
L'archive ouverte pluridisciplinaire HAL, est destinée au dépôt et à la diffusion de documents scientifiques de niveau recherche, publiés ou non, émanant des établissements d'enseignement et de recherche français ou étrangers, des laboratoires publics ou privés. 
Article

\title{
Desert Roughness Retrieval Using CYGNSS GNSS-R Data
}

\author{
Donato Stilla ${ }^{1,2}{ }^{(D}$, Mehrez Zribi ${ }^{1, *} \mathbb{C}^{-}$, Nazzareno Pierdicca ${ }^{2}$, Nicolas Baghdadi ${ }^{3}(\mathbb{D}$ and \\ Mireille Huc ${ }^{1}$ \\ 1 CESBIO, (CNRS/UPS/IRD/CNES/INRAE), 18 av. Edouard Belin, bpi 2801, 31401 Toulouse CEDEX 9, France; \\ donystilla@hotmail.it (D.S.); mireille.huc@cesbio.cnes.fr (M.H.) \\ 2 Department of Information Engineering, Electronics, Telecommunications, University of La Sapienza, \\ Via Eudossiana 18, 00184 Rome, Italy; nazzareno.pierdicca@uniroma1.it \\ 3 INRAE, TETIS, University of Montpellier, 34093 Montpellier CEDEX 5, France; \\ nicolas.baghdadi@teledetection.fr \\ * Correspondence: mehrez.zribi@ird.fr; Tel.: +33-561558525
}

Received: 20 January 2020; Accepted: 21 February 2020; Published: 24 February 2020

\begin{abstract}
The aim of this paper is to assess the potential use of data recorded by the Global Navigation Satellite System Reflectometry (GNSS-R) Cyclone Global Navigation Satellite System (CYGNSS) constellation to characterize desert surface roughness. The study is applied over the Sahara, the largest non-polar desert in the world. This is based on a spatio-temporal analysis of variations in Cyclone Global Navigation Satellite System (CYGNSS) data, expressed as changes in reflectivity $(\Gamma)$. In general, the reflectivity of each type of land surface (reliefs, dunes, etc.) encountered at the studied site is found to have a high temporal stability. A grid of CYGNSS $\Gamma$ measurements has been developed, at the relatively fine resolution of $0.03^{\circ} \times 0.03^{\circ}$, and the resulting map of average reflectivity, computed over a 2.5-year period, illustrates the potential of CYGNSS data for the characterization of the main types of desert land surface (dunes, reliefs, etc.). A discussion of the relationship between aerodynamic or geometric roughness and CYGNSS reflectivity is proposed. A high correlation is observed between these roughness parameters and reflectivity. The behaviors of the GNSS-R reflectivity and the Advanced Land Observing Satellite-2 (ALOS-2) Synthetic Aperture Radar (SAR) backscattering coefficient are compared and found to be strongly correlated. An aerodynamic roughness $\left(\mathrm{Z}_{0}\right)$ map of the Sahara is proposed, using four distinct classes of terrain roughness.
\end{abstract}

Keywords: CYGNSS; GNSS-R; ALOS-2; roughness; aerodynamic roughness; desert

\section{Introduction}

Desert areas play an essential role in regional climates, due primarily to the transfer of aerosols [1-3]. In this context, numerous studies have mapped the properties of desert surfaces, in particular parameters such as their aerodynamic roughness. Prigent et al. (2005) [4] proposed the mapping of the aerodynamic roughness length (Z0) using data from the European Remote-Sensing Satellite (ERS) scatterometer. $\mathrm{Z} 0$ is defined as the height above the displacement plane at which the mean wind becomes zero when extrapolating the logarithmic wind speed profile downward through the surface layer. These authors have shown the ability of this instrument to distinguish between different classes of aerodynamic roughness Z0, which can then be used as input data for aerosol transfer models [5]. Simultaneous, high spatial resolution low frequency SAR radar data can also be used to characterize the geometric roughness of surfaces, generally defined by two statistical parameters calculated from the height autocorrelation function: i.e., the Root Mean Square Height (rmsh) (vertical statistical parameter) and correlation length (horizontal statistical parameter) [6-9]. Roughness information can be exploited to gain insight into sub-surface properties through the strong penetration of electromagnetic waves [10-12]. 
In this context, over the last 15 years, we have witnessed the arrival of GNSS-R (Global Navigation Satellite System Reflectometry) technology, which initially demonstrated its considerable potential for the characterization of ocean surface properties (waves, etc.) [13-17]. It was then tested over continental surfaces, where it revealed its strong potential for the monitoring of various surface parameters such as the water content of the soil or vegetation biomass [18-25]. Following various recent in situ and airborne campaigns collecting GNSS-R measurements [22,26,27], several studies have illustrated their potential for the development of GNSS-R based applications [28-38]. [28,31,33] have shown the strong potential of GNSS-R TechDemoSat-1 receiver and reflections collected by the SMAP (Soil Moisture Active Passive) receiver for the mapping of surface conditions, such as soil moisture or vegetation properties. In this context, it has been shown that surface scattering is predominantly coherent over flat land surfaces, if we may neglect the effect of topography [39].

The CYGNSS mission, developed by the University of Michigan and the Southwest Research Institute and sponsored by National Aeronautics and Space Administration (NASA), was launched in 2017 [40]. It was designed to improve hurricane forecasting with measurements of wind speed and to study interactions between air and water surfaces during the tropical cyclone season, including in high precipitation conditions. This satellite system comprises eight micro-satellites, fitted with the Global Positioning System (GPS) receiver payloads. These are referred to as Delay Doppler Map Instruments (DDMI), and their operating principle relies on the reception of the GPS signal powers reflected by the Earth's surface, given as a function of the delay and Doppler shift. The CYGNSS constellation offers high space-time sampling of several geophysical variables, thanks to the simultaneous collection, by each CYGNSS satellite, of the signals transmitted by four GPS satellites and then scattered by the ocean or terrain. Various studies have been proposed to estimate land surface properties, such as soil moisture and vegetation biomass [34-38].

The aim of the present study is to analyze, for the first time, the potential of CYGNSS GNSS-R data for desert surface applications. This paper is organized as follows: Section 2 provides a general description of the studied site and the datasets considered in this study; Section 3 describes the methodology used to interpret and map the CYGNSS data recorded over the Sahara; Section 4 focuses on the results, and discusses the relationship between reflectivity and surface roughness (aerodynamic or geometric); finally, our conclusions are provided in Section 5.

\section{Studied Site and Database}

\subsection{Studied Site}

The results described and discussed in this paper refer to data recorded over the Sahara Desert in North Africa (Figure 1); the considered areas are situated between $15^{\circ} 0^{\prime} \mathrm{N}$ and $37^{\circ} 30^{\prime} \mathrm{N}$ and between $17^{\circ} 0^{\prime} \mathrm{W}$ and $39^{\circ} 30^{\prime} \mathrm{E}$, with some specific areas being selected for further analysis. The Sahara contains a large number of heterogeneous environments: sand dunes, flat rocky surfaces, high mountains and volcanic rocks. Furthermore, the Sahara encompasses various distinctly different climate zones, including a Mediterranean climate along its northern extremity, an extremely arid central zone with rare rainfall events, and a southern zone, which receives some rain during the monsoon season. 


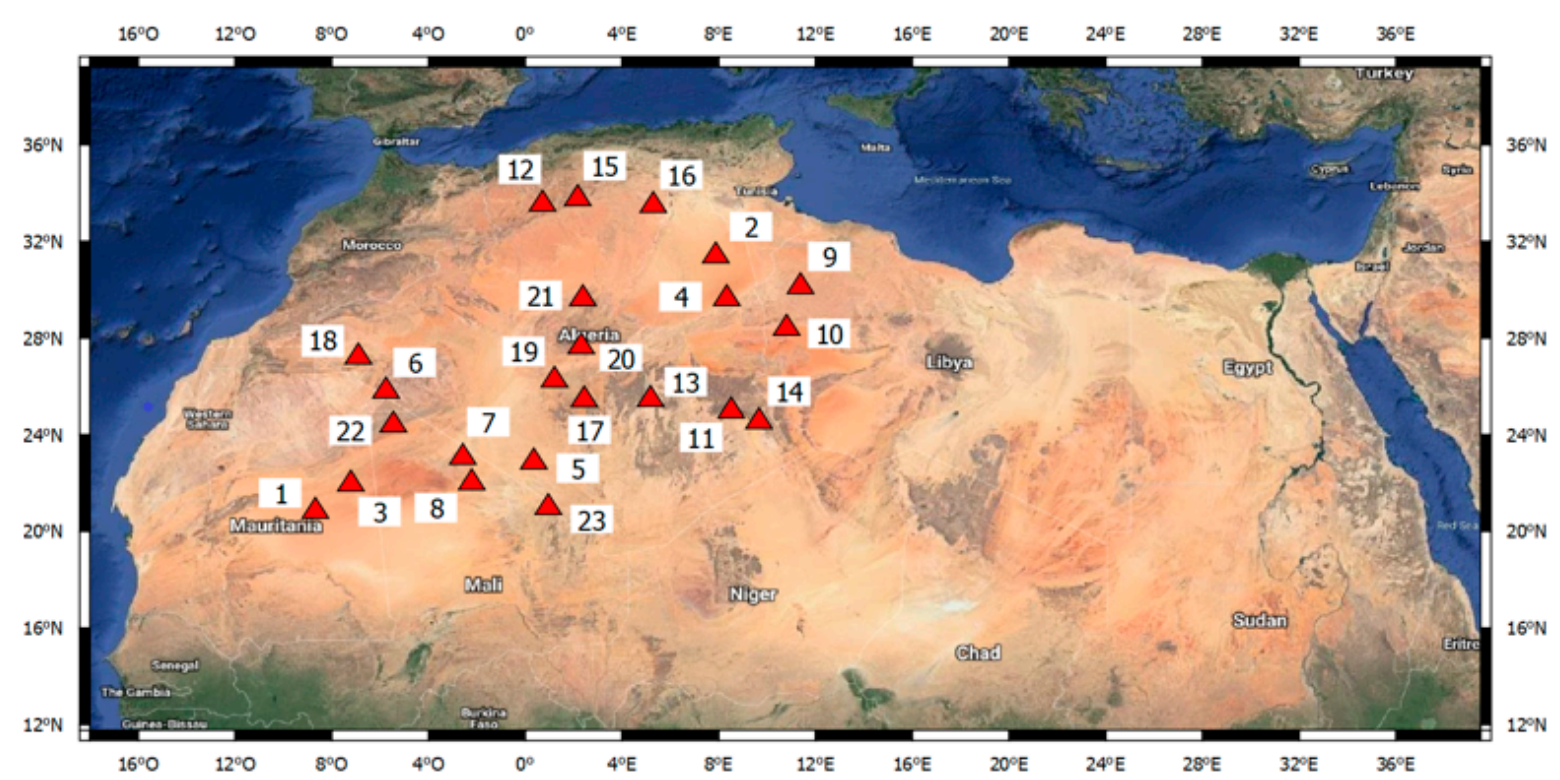

Figure 1. Illustration of the studied site: the Sahara desert.

\subsection{Database}

\subsubsection{Satellite Data}

\section{(a) CYGNSS data}

The main dataset used for this analysis is the Level 1 (L1) CYGNSS 0 data, version 2.1, obtainable from the Physical Oceanography Distributed Active Archive Center (PODAAC) (https://podaac.jpl. nasa.gov). The L1 data are stored as daily Network Common Data Form (NETCDF) files, in which each day is represented by eight files (one for each CYGNSS platform), with each of these containing a large number of useful variables that can be used for the subsequent processing steps. The main pieces of information are the Delay/Doppler Maps (DDMs) of the analogue scattered power. For each data point, the specular point properties (i.e., the DDM sample corresponding to the point on the surface minimum electromagnetic path length) are taken into account, together with several geometrical parameters relevant to each acquisition (e.g., specular point incidence angle, transmitter and receiver ranges, etc.), and metadata related to the quality of the incoming and reflected GPS signals (e.g., direct Signal to Noise Ratio (SNR), receiver gain, SNR for each DDM etc.). In this research, almost 2.5 years of CYGNSS acquisitions, recorded between March 2017 and July 2019, have been processed and analyzed. In order to filter the data correctly, bitwise quality flags are provided to select the best data, and in the present study, all available quality flags were considered and set to 1 [41,42]. The theoretical footprint of a reflected GNSS signal is $\sim 0.5 \times 0.5 \mathrm{~km}$, for the case of a smooth surface and a receiver at the altitude of CYGNSS. The receivers integrate signals over $1 \mathrm{~s}$. During this period of time, the receiver travels $\sim 7 \mathrm{~km}$. Thus, the smallest area of ground from which reflections are received is $\sim 7 \times 0.5 \mathrm{~km}$.

The signal over land includes both coherent and incoherent scattering, with a relative weight that is subject to discussion $[43,44]$. The main observables related to the two mechanisms are the reflectivity and the Normalized Radar Cross Section, respectively. Here, we refer to the reflectivity $(\Gamma)$, which should then be considered as an "equivalent reflectivity" that is derived from the CYGNSS data as suggested in [35] using the following expression:

$$
\Gamma(\theta)=\frac{(4 \pi)^{2}\left(P_{D D M}-N\right)\left(R_{r}+R_{t}\right)^{2}}{\lambda^{2} G_{r} G_{t} P_{t}}
$$

where $P_{D D M}$ is the maximum value of the analog power in the Delay/Doppler Maps (DDM), $N$ is the noise floor related to the DDM, $R_{r}$ is the receiver-specular point (SP) distance, $R_{t}$ is the transmitter-specular 
point (SP) distance, $\lambda$ is the wave length, $\theta$ is the incidence angle, $G_{r}$ is the receiver antenna gain in the direction of the specular point (SP) and $G_{t} P_{t}$ is the transmitter equivalent isotropically radiated power (EIRP). The noise floor is computed as the mean value of the DDM subset, when the signal is absent (located above the characteristic horseshoe shape of the DDMs) as suggested, for example, in [35].

The data are collected in daily data frames, taking into account various empirical filters used to remove noisy data, which could otherwise be expected to degrade the quality of the imagery and subsequent analysis.

The filtering criteria considered for this purpose were the following:

(1) CYGNSS reflectivity values should range between $-35 \mathrm{~dB}$ and $-5 \mathrm{~dB}$;

(2) Incidence angles should range between $0^{\circ}$ and $30^{\circ}$;

(3) DDM signal-to-noise ratio (SNR) should be greater than $3 \mathrm{~dB}$;

(4) $G_{r x}$ (receiver antenna gain towards SP) should be greater than $5 \mathrm{~dB}$;

(5) Data corresponding to terrain at altitudes greater than $650 \mathrm{~m}$ above the WGS84 ellipsoid model of the Earth should be removed.

Altitudes greater than $650 \mathrm{~m}$ are not taken into account, in order to ensure that the detected reflections occur within the Delay/Doppler acquisition window, which is reduced and compressed for DDMs released as L1 CYGNSS products [45].

(b) ALOS-2 data

The open dataset provided by the ALOS-2 mission, an advanced L-band platform developed by Japan Aerospace Exploration Agency (JAXA), is considered. The data are recorded at a global resolution of $25 \mathrm{~m}$, created by mosaicking SAR images of backscattering coefficients, which were measured by the Phased Array type L-band Synthetic Aperture Radar 2 (PALSAR-2), freely available at the JAXA Earth Observation Research Center (EORC/JAXA) (https://www.eorc.jaxa.jp/ALOS/en/ palsar_fnf/data/index.htm). Each file contains pre-processed information related to the local incidence angle, acquisition date, and the backscattering coefficient for the horizontal-horizontal (HH) and horizontal-vertical (HV) polarizations. The pre-processing includes ortho-rectification (correction of geometric distortion) and slope correction (topographic effects on image intensity). In the present paper, HH backscattering maps from the year 2017 are used, whereas the HV data are not analyzed due to their greater sensitivity to volume rather than surface scattering. As described in the PALSAR-2 handbook [46], the backscattering maps are not calibrated, and the results are provided in the form of digital counts. In practice, a calibration coefficient is needed to transform the product into a more convenient decimal format, according to the following expression:

$$
\left.\sigma_{o}\right|_{d B}=10 \log _{10}\left(D N^{2}\right)+C F
$$

where $\sigma_{0}$ is the output backscattering coefficient in decibels, $\mathrm{DN}$ is the input digital number contained in the dataset, and CF is the calibration factor, which is set to $-83 \mathrm{~dB}$ [47].

(c) SRTM

The altitude values, along with quantities derived from the height of the terrain, were retrieved from the Shuttle Radar Topography Mission (SRTM) data, which provides a three arcsec $(90 \mathrm{~m})$ gridded, near-global scale digital elevation model (DEM) between $56^{\circ} \mathrm{S}$ and $60^{\circ} \mathrm{N}$, produced by NASA-Jet Propulsion Laboratory (JPL) and available online at: http://srtm.csi.cgiar.org/srtmdata/.

\subsubsection{Ground Measurements of Aerodynamic Roughness}

In this study, we made use of ground measurements of aerodynamic roughness, measured over the Sahara desert, provided in the study of Marticorena et al. (1997) [5]. As listed in Table 1, 23 areas are considered, corresponding to a wide range of surface conditions (dunes, smooth surfaces, reliefs 
etc.). The same database was also used in the past to develop aerodynamic roughness maps, based on data recorded by the ERS scatterometer [4].

Table 1. Aerodynamic roughness ground measurements over the Sahara site [5].

\begin{tabular}{|c|c|c|c|c|c|}
\hline \multirow{2}{*}{$\begin{array}{c}\text { Number } \\
1\end{array}$} & \multirow{2}{*}{$\begin{array}{c}\text { Regions } \\
\text { Adrar Desert-Mauritania }\end{array}$} & \multirow{2}{*}{$\begin{array}{c}\text { Type of Terrain } \\
\text { Dunes }\end{array}$} & \multicolumn{2}{|c|}{ Coordinates } & \multirow{2}{*}{$\begin{array}{r}Z_{0}[\mathrm{~cm}] \\
0.0023\end{array}$} \\
\hline & & & $\begin{array}{l}20^{\circ} 44^{\prime} \mathrm{N} \\
9^{\circ} 44^{\prime} \mathrm{W}\end{array}$ & $\begin{array}{l}20^{\circ} 18^{\prime} \mathrm{N} \\
9^{\circ} 18^{\prime} \mathrm{W}\end{array}$ & \\
\hline 2 & Great Eastern Erg—Algeria & Dunes & $\begin{array}{l}31^{\circ} 36^{\prime} \mathrm{N} \\
7^{\circ} 00^{\prime} \mathrm{E}\end{array}$ & $\begin{array}{l}31^{\circ} 14^{\prime} \mathrm{N} \\
7^{\circ} 25^{\prime} \mathrm{E}\end{array}$ & 0.0023 \\
\hline 3 & Adrar Desert-Mauritania & Dunes & $\begin{array}{l}21^{\circ} 48^{\prime} \mathrm{N} \\
7^{\circ} 42^{\prime} \mathrm{W}\end{array}$ & $\begin{array}{l}21^{\circ} 20^{\prime} \mathrm{N} \\
7^{\circ} 15^{\prime} \mathrm{W}\end{array}$ & 0.0023 \\
\hline 4 & Great Eastern Erg_Algeria & Dunes & $\begin{array}{l}31^{\circ} 39^{\prime} \mathrm{N} \\
8^{\circ} 34^{\prime} \mathrm{E}\end{array}$ & $\begin{array}{l}31^{\circ} 13^{\prime} \mathrm{N} \\
9^{\circ} 03^{\prime} \mathrm{E}\end{array}$ & 0.0023 \\
\hline 5 & Bordj Badji Mokhtar-Algeria & Sandy flat surface & $\begin{array}{c}23^{\circ} 42^{\prime} \mathrm{N} \\
0^{\circ} 59^{\prime} \mathrm{E}\end{array}$ & $\begin{array}{c}23^{\circ} 18^{\prime} \mathrm{N} \\
1^{\circ} 22^{\prime} \mathrm{E}\end{array}$ & 0.01 \\
\hline 6 & $\begin{array}{c}\text { Tiris Zemmour } \\
\text { Plateau—Mauritania }\end{array}$ & Rocky surface & $\begin{array}{l}26^{\circ} 12^{\prime} \mathrm{N} \\
7^{\circ} 48^{\prime} \mathrm{W}\end{array}$ & $\begin{array}{l}25^{\circ} 48^{\prime} \mathrm{N} \\
7^{\circ} 18^{\prime} \mathrm{W}\end{array}$ & 0.025 \\
\hline 7 & Tamanrasset-Algeria & Rocky surface & $\begin{array}{l}21^{\circ} 42^{\prime} \mathrm{N} \\
5^{\circ} 20^{\prime} \mathrm{E}\end{array}$ & $\begin{array}{l}21^{\circ} 15^{\prime} \mathrm{N} \\
5^{\circ} 48^{\prime} \mathrm{E}\end{array}$ & 0.05 \\
\hline 8 & Tamanrasset-Algeria & Rocky surface & $\begin{array}{c}21^{\circ} 40^{\prime} \mathrm{N} \\
4^{\circ} 20^{\prime} \mathrm{E}\end{array}$ & $\begin{array}{c}21^{\circ} 21^{\prime} \mathrm{N} \\
4^{\circ} 48^{\prime} \mathrm{E}\end{array}$ & 0.05 \\
\hline 9 & $\begin{array}{l}\text { Nafusah Plateau, } \\
\text { Tripolitania-Libya }\end{array}$ & Rocky surface & $\begin{array}{l}30^{\circ} 42^{\prime} \mathrm{N} \\
11^{\circ} 09^{\prime} \mathrm{E}\end{array}$ & $\begin{array}{l}30^{\circ} 15^{\prime} \mathrm{N} \\
11^{\circ} 12^{\prime} \mathrm{E}\end{array}$ & 0.15 \\
\hline 10 & Ubari Desert—Libya & $\begin{array}{l}\text { Rocky surface } \\
\text { (hammada) }\end{array}$ & $\begin{array}{l}30^{\circ} 10^{\prime} \mathrm{N} \\
10^{\circ} 45^{\prime} \mathrm{E}\end{array}$ & $\begin{array}{l}29^{\circ} 45^{\prime} \mathrm{N} \\
11^{\circ} 12^{\prime} \mathrm{E}\end{array}$ & 0.15 \\
\hline 11 & $\begin{array}{c}\text { Tassili N'Ajjer } \\
\text { Mountains-Algeria }\end{array}$ & Mountains & $\begin{array}{l}25^{\circ} 42^{\prime} \mathrm{N} \\
8^{\circ} 10^{\prime} \mathrm{E}\end{array}$ & $\begin{array}{l}25^{\circ} 18^{\prime} \mathrm{N} \\
8^{\circ} 32^{\prime} \mathrm{E}\end{array}$ & 0.5 \\
\hline 12 & Atlas Mountains_-Algeria & Mountains & $\begin{array}{l}33^{\circ} 36^{\prime} \mathrm{N} \\
1^{\circ} 18^{\prime} \mathrm{W}\end{array}$ & $\begin{array}{l}33^{\circ} 12^{\prime} \mathrm{N} \\
0^{\circ} 48^{\prime} \mathrm{W}\end{array}$ & 0.873 \\
\hline 13 & Tanezrouft-Algeria & Rocky surface & $\begin{array}{l}26^{\circ} 42^{\prime} \mathrm{N} \\
4^{\circ} 54^{\prime} \mathrm{W}\end{array}$ & $\begin{array}{l}26^{\circ} 18^{\prime} \mathrm{N} \\
4^{\circ} 27^{\prime} \mathrm{W}\end{array}$ & 0.05 \\
\hline 14 & $\begin{array}{c}\text { Tassili N'Ajjer } \\
\text { Mountains-Algeria }\end{array}$ & Mountains & $\begin{array}{l}26^{\circ} 12^{\prime} \mathrm{N} \\
8^{\circ} 17^{\prime} \mathrm{E}\end{array}$ & $\begin{array}{c}25^{\circ} 46^{\prime} \mathrm{N} \\
8^{\circ} 32^{\prime} \mathrm{E}\end{array}$ & 0.5 \\
\hline 15 & Atlas Mountains-Algeria & Mountains & $\begin{array}{c}33^{\circ} 28^{\prime} \mathrm{N} \\
2^{\circ} 53^{\prime} \mathrm{E}\end{array}$ & $\begin{array}{l}33^{\circ} 12^{\prime} \mathrm{N} \\
3^{\circ} 30^{\prime} \mathrm{E}\end{array}$ & 0.347 \\
\hline 16 & Ouled Nail Mountains_-Algeria & Mountains & $\begin{array}{l}33^{\circ} 37^{\prime} \mathrm{N} \\
3^{\circ} 31^{\prime} \mathrm{E}\end{array}$ & $\begin{array}{c}33^{\circ} 12^{\prime} \mathrm{N} \\
4^{\circ} 01^{\prime} \mathrm{E}\end{array}$ & 0.347 \\
\hline 17 & El Eglab Massif-Algeria & Mountains & $\begin{array}{l}26^{\circ} 59^{\prime} \mathrm{N} \\
3^{\circ} 44^{\prime} \mathrm{W}\end{array}$ & $\begin{array}{l}26^{\circ} 46^{\prime} \mathrm{N} \\
3^{\circ} 09^{\prime} \mathrm{W}\end{array}$ & 0.131 \\
\hline 18 & Hammada du Draa-Morocco & $\begin{array}{l}\text { Rocky surface } \\
\text { (hammada) }\end{array}$ & $\begin{array}{l}27^{\circ} 47^{\prime} \mathrm{N} \\
8^{\circ} 43^{\prime} \mathrm{W}\end{array}$ & $\begin{array}{l}27^{\circ} 28^{\prime} \mathrm{N} \\
8^{\circ} 17^{\prime} \mathrm{W}\end{array}$ & 0.131 \\
\hline 19 & Tidikelt Plain—Algeria & Sandy flat surface & $\begin{array}{c}26^{\circ} 41^{\prime} \mathrm{N} \\
2^{\circ} 00^{\prime} \mathrm{E}\end{array}$ & $\begin{array}{c}27^{\circ} 09^{\prime} \mathrm{N} \\
2^{\circ} 24^{\prime} \mathrm{E}\end{array}$ & 0.0873 \\
\hline 20 & Tademait Plateau_Algeria & Sandy flat surface & $\begin{array}{c}28^{\circ} 41^{\prime} \mathrm{N} \\
2^{\circ} 40^{\prime} \mathrm{E}\end{array}$ & $\begin{array}{l}28^{\circ} 09^{\prime} \mathrm{N} \\
2^{\circ} 55^{\prime} \mathrm{E}\end{array}$ & 0.0873 \\
\hline 21 & $\begin{array}{c}\text { Hassi Gara, Great Western } \\
\text { Erg-Algeria }\end{array}$ & Sandy flat surface & $\begin{array}{l}29^{\circ} 46^{\prime} \mathrm{N} \\
2^{\circ} 58^{\prime} \mathrm{E}\end{array}$ & $\begin{array}{l}29^{\circ} 14^{\prime} \mathrm{N} \\
3^{\circ} 35^{\prime} \mathrm{E}\end{array}$ & 0.0873 \\
\hline 22 & $\begin{array}{c}\text { Tiris Zemmour } \\
\text { Plateau-Mauritania }\end{array}$ & Sandy flat surface & $\begin{array}{l}23^{\circ} 50^{\prime} \mathrm{N} \\
7^{\circ} 52^{\prime} \mathrm{W}\end{array}$ & $\begin{array}{l}23^{\circ} 27^{\prime} \mathrm{N} \\
7^{\circ} 37^{\prime} \mathrm{W}\end{array}$ & 0.0174 \\
\hline 23 & Tanerzrouft-n-Ahnet-Algeria & Sandy flat surface & $\begin{array}{c}22^{\circ} 30^{\prime} \mathrm{N} \\
0^{\circ} 53^{\prime} \mathrm{E}\end{array}$ & $\begin{array}{c}22^{\circ} 17^{\prime} \mathrm{N} \\
0^{\circ} 37^{\prime} \mathrm{E}\end{array}$ & 0.01 \\
\hline
\end{tabular}




\section{Methodology}

This section proposes a methodology to process CYGNSS data over desert surfaces.

\subsection{CYGNSS Data Normalisation}

Several studies have highlighted the influence of incidence angle on reflectivity, and in the present study, the role of this effect needs to be assessed for different types of surface topography. In Figure 2, the computed reflectivity derived from Equation (1) is plotted as a function of the incidence angle for two different areas with the whole temporal dataset. These test areas are described in Table 2.

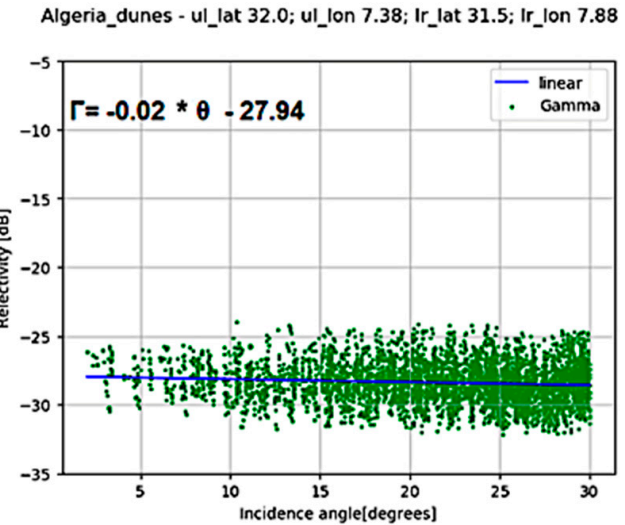

(a)

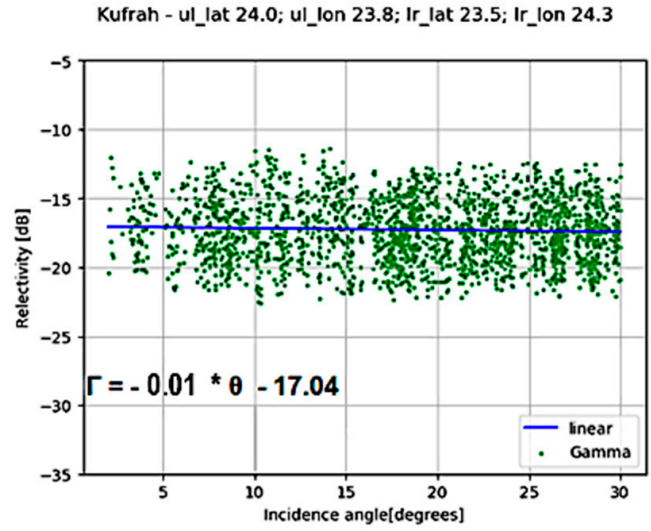

(b)

Figure 2. Plot of variations in Cyclone Global Navigation Satellite System (CYGNSS) reflectivity as a function of incidence angles: (a) Algeria dunes, (b) Kufrah area.

Table 2. Coordinates of test areas used for CYGNSS data processing.

\begin{tabular}{ccc}
\hline Regions & \multicolumn{2}{c}{ Coordinates } \\
\hline $\begin{array}{c}\text { Great Eastern Erg-Algeria } \\
\text { (Algeria dunes) }\end{array}$ & $31^{\circ} 51^{\prime} \mathrm{N} \cdots 7^{\circ} 33^{\prime} \mathrm{E}$ & $31^{\circ} 45^{\prime} \mathrm{N} \cdots 7^{\circ} 39^{\prime} \mathrm{E}$ \\
\hline $\begin{array}{c}\text { Great Libyan Desert-Egypt } \\
\text { (Egypt dunes) }\end{array}$ & $28^{\circ} \mathrm{N} \cdots 25^{\circ} 36^{\prime} \mathrm{E}$ & $27^{\circ} 54^{\prime} \mathrm{N} \cdots 25^{\circ} 42^{\prime} \mathrm{E}$ \\
\hline Kufrah Basin-Libya & $23^{\circ} 54^{\prime} \mathrm{N} \cdots 24^{\circ} 9^{\prime} \mathrm{E}$ & $23^{\circ} 48^{\prime} \mathrm{N} \cdots 24^{\circ} 15^{\prime} \mathrm{E}$ \\
\hline Tamanarasset (Mali) & $23^{\circ} 49^{\prime} \mathrm{N} \cdots 4^{\circ} 46^{\prime} \mathrm{W}$ & $23^{\circ} 43^{\prime} \mathrm{N} \cdots 4^{\circ} 40^{\prime} \mathrm{W}$ \\
\hline
\end{tabular}

It can be seen that the incidence angle has a very limited effect for incidence angle values between $2^{\circ}$ and $30^{\circ}$.

As shown in Figure 2, a simple linear normalization is thus proposed, referring to an incidence angle of $20^{\circ}$, in order to account for the small influence of the incidence angle on the reflectivity. We use the following expression:

$$
\Gamma\left(20^{\circ}\right)=\Gamma(\theta)-\mathrm{A} \cdot\left(\theta-20^{\circ}\right)
$$

where the parameter $\mathrm{A}$ is the slope of the retrieved least squares linear relationship between reflectivity and incidence angle for a given type of surface.

In our context, with a limited time series of CYGNSS data, the azimuth angle effect is not considered in the proposed data analysis. This effect is negligible for land surfaces, particularly after data temporal averaging.

\subsection{Temporal Stability of CYGNSS Data}

In the case of desert areas, remotely sensed signals, and in particular microwave measurements, are in general found to be very stable $[7,8]$. In this context, in order to ensure that the retrieved values 
of reflectivity are accurate, it is essential to evaluate their temporal stability. Figure 3 plots the signals retrieved in the four areas cited in Table 2, characterizing different types of surface (dunes, smooth surfaces, relief). A 2.5-year time series is shown for each zone, with the plotted values corresponding to the mean reflectivity within a 3-month period and a relatively small $\left(0.1^{\circ} \times 0.1^{\circ}\right)$ zone. For some months of the year, no data were available since no specular points corresponding to such a small zone were detected. The reflectivities plotted in Figure 3 confirm the high temporal stability of the reflectivity data, with a negligible standard deviation (std dev), less than $0.7 \mathrm{~dB}$ for three of these sites.

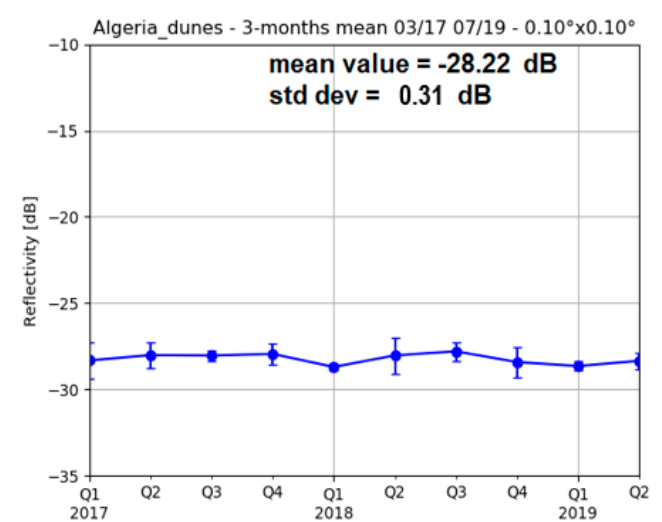

(a)

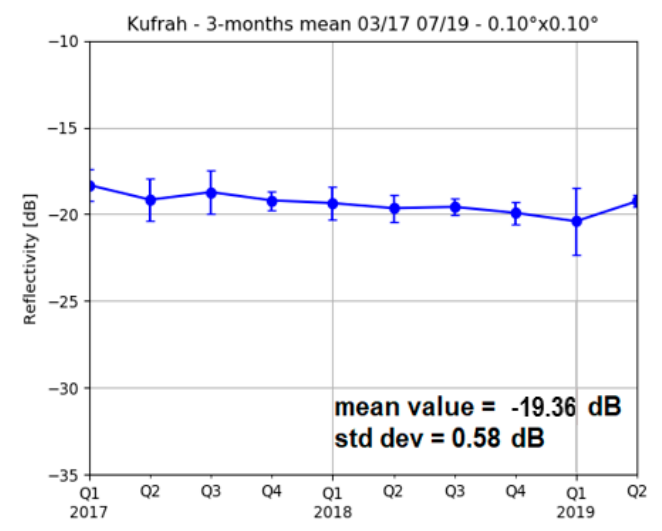

(c)

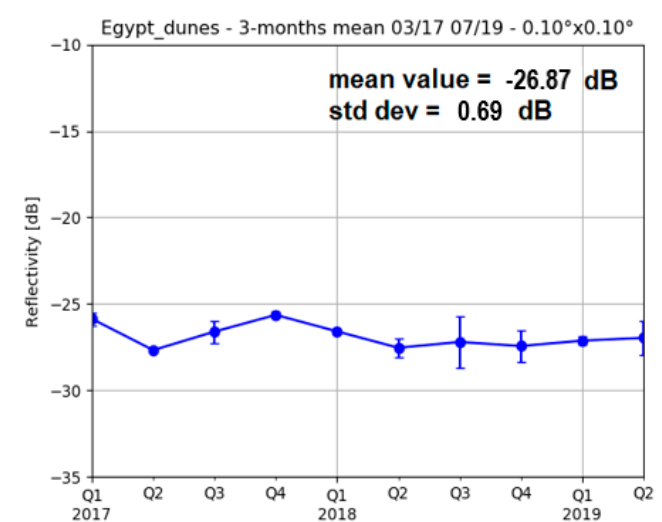

(b)

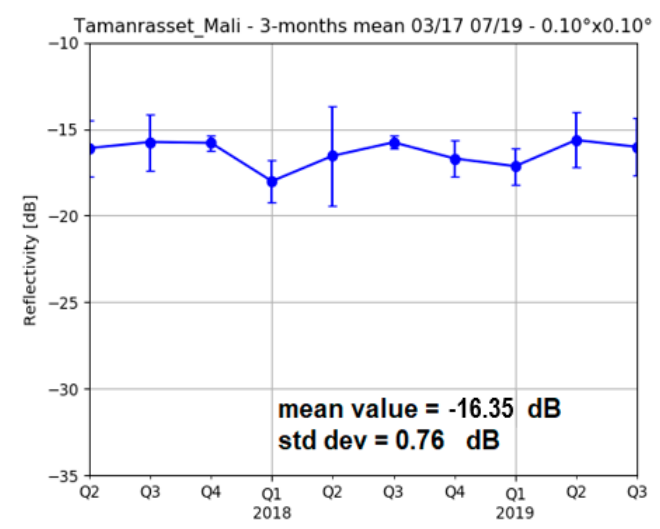

(d)

Figure 3. Temporal variations of CYGNSS reflectivity over a period of 2.5 years: (a) Algerian dunes, (b) Egypt dunes, (c) Kufrah (Libya), (d) Tamanrasset-Mali.

In the lower right graph (Figure 3d), corresponding to the fourth site, Tamanrasset-Mali, small seasonal effects are revealed by variations in reflectivity; in particular, towards the end of the summer of 2018. A clear correlation can be seen between the peak of the monsoon season in the Sahel region, which falls between August and September, and the peak in reflectivity at Tamanrasset in $2018(-15.5$ $\mathrm{dB}$ for Q3). The reflectivity observed for July-September is approximately $+2.26 \mathrm{~dB}$ greater than that observed in January. This is certainly due to the monsoon rainfall [48], which increases the dielectric constant of the soil and leads to higher values of reflectivity.

\subsection{Reflectivity Mapping over Sahara}

Following the normalization of the CYGNSS measurements and validation of the stability of the Sahara's reflectivity during the studied period, the data were arranged in a grid format, each pixel of which corresponds to the mean value over the full period of observation; i.e., nearly 2.5 years. The challenge of this process is to retain the finest possible grid resolution, with the constraint of using a sufficiently large number of observations to ensure the accuracy of the resulting average value. 
For this purpose, three different resolutions were tested. Figure 4 shows the reflectivity histograms obtained with resolutions of $0.1^{\circ}, 0.05^{\circ}$ and $0.03^{\circ}$ (close to $3.5 \mathrm{~km}$ ), and simple Gaussian distributions fitting the experimental data. It can be seen that this approximation is better adapted to the Sudan-Nile site (Figure $4 b$ ) than to the Kufrah site (Figure $4 a$ ). This could be explained by the presence of strong heterogeneities at the former site, which includes both flat and mountainous areas.

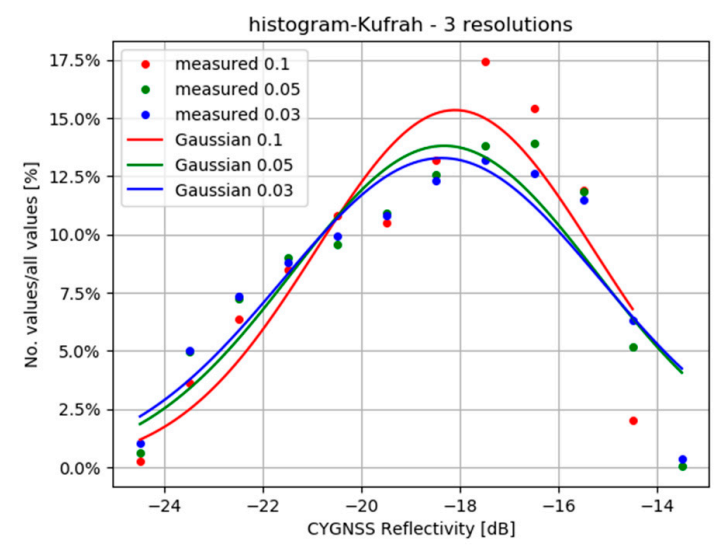

(a)

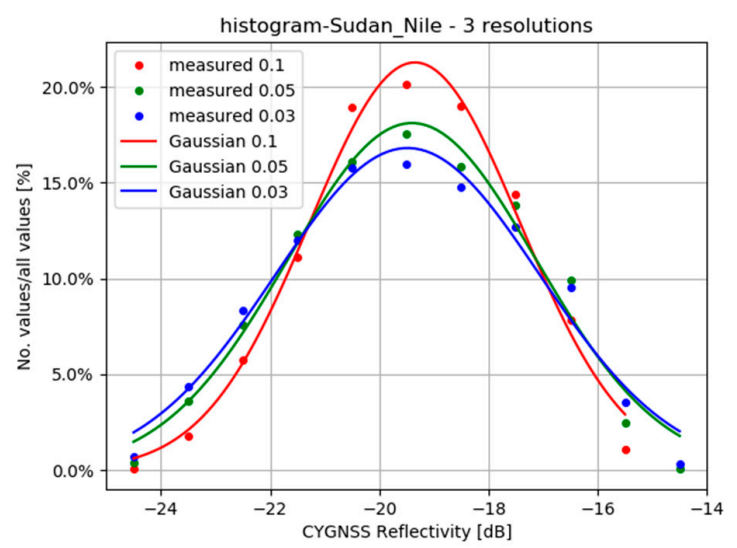

(b)

Figure 4. Reflectivity histograms for three spatial resolutions: $0.1^{\circ}, 0.05^{\circ}$ and $0.03^{\circ}$, at two different locations: (a) Kufrah area (Libya), (b) Sudan-Nile area.

At a resolution of $0.1^{\circ}$, the data are smoothed by relatively high spatial averaging, such that the dynamic range (very low or very high reflectivity) is very much reduced. This corresponds to a stronger degradation (smoothing) of fine geometric structures when compared to the results obtained at higher resolutions; i.e., $0.05^{\circ}$ and $0.03^{\circ}$. At these finer resolutions, very similar histograms are observed. We finally chose the grid at a resolution of $0.03^{\circ}$, thus allowing the finest possible geometrical structures to be resolved from the processed data. It is interesting to confirm that this corresponds to a CYGNSS spatial resolution of about $3.5 \mathrm{~km}$. It is important to note that the purely coherent signal has a spatial resolution corresponding to the first Fresnel zone [44], whereas the spatial resolution $(\sim 25 \mathrm{~km})$ of the purely incoherent signal, represented by an iso-delay ellipse projected on the ground, depends on the chip range resolution $(\sim 300 \mathrm{~m})$ of the GPS L1 C/A signal. This empirical result shows that we can distinguish details, which are larger than the Fresnel zone, but also much smaller than the resolution of the incoherent signal.

Once the $0.03^{\circ}$ resolution was selected, a minimum number of measurements (four CYGNSS data points) was used to achieve a reliable time average for each pixel. This threshold was determined empirically, using qualitative observations of retrieved maps, and our analysis of the sensitivity of the estimated reflectivity to the number of measurements.

Grid points that were not covered by four measurements were not included in the final grid. These points correspond mainly to high altitude zones $(>650 \mathrm{~m})$, for which the data were not analyzed (see above regarding data filtering). Figure 5 shows the resulting reflectivity map at a resolution of $0.03^{\circ} \times 0.03^{\circ}$, which covers the latitudes between $15^{\circ} \mathrm{N}$ and $37^{\circ} 30^{\prime} \mathrm{N}$ and the longitudes between $17^{\circ} \mathrm{W}$ and $39^{\circ} 30^{\prime} \mathrm{E}$. Mountainous regions higher than $650 \mathrm{~m}$-for example, the Hoggar Mountains in the South-East of Algeria, the Tibesti Mountains in the southern Libya, and the Atlas Mountains in the North-East of Morocco (Maghreb) - are not mapped. Regions with sand dunes, such as the Western and Eastern Erg in the North-West and North-East of Algeria respectively, the Great Libyan Desert in the East of Libya bordering with Egypt, and the Aoukar Erg in the South-East of Mauritania, are recognizable by their lower received signals due probably to a high wave penetration in soil. In Figure 5, mountains and areas with low received signals are masked in white. 


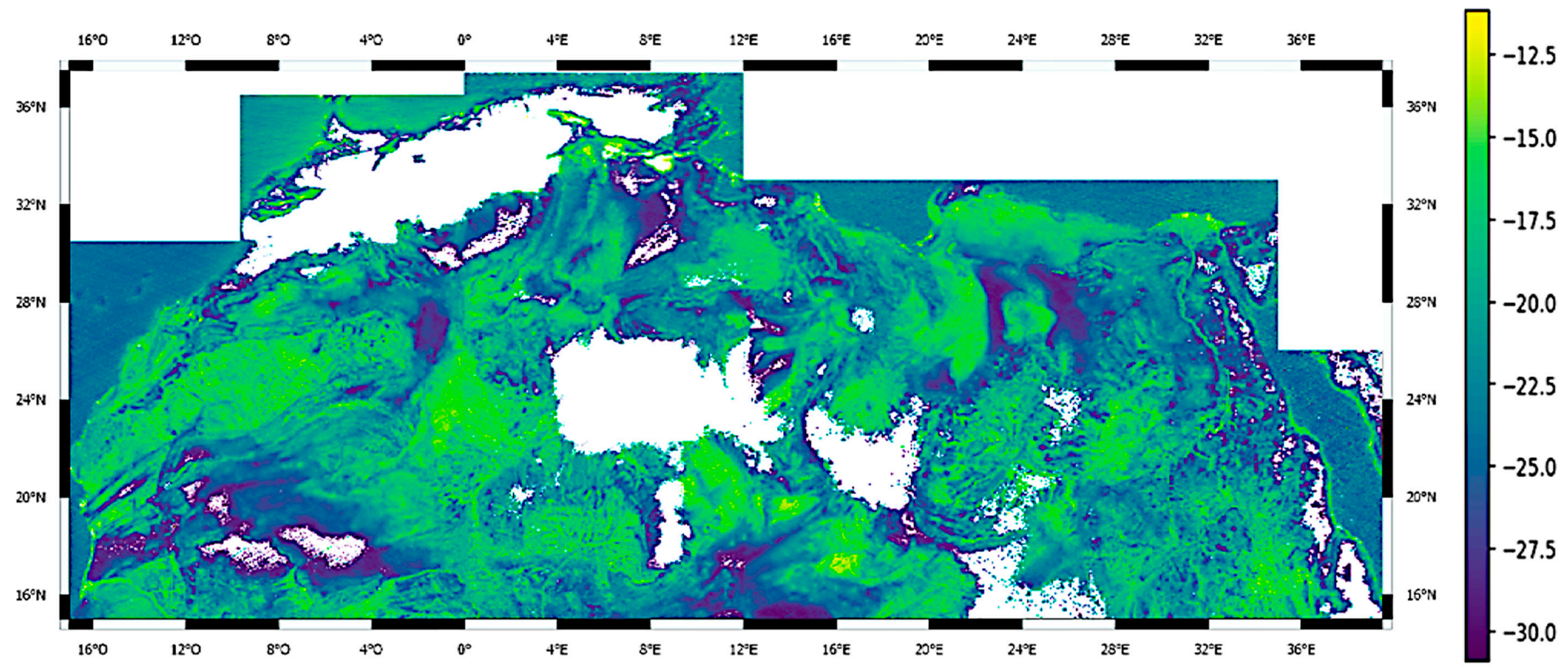

Figure 5. Average reflectivity (dB) map (mosaic) of the Sahara region, with a gridded-pixel size of $0.03^{\circ} \times 0.03^{\circ}$. Mountains and areas with low received signals are masked (white color). 


\section{Results and Discussions}

In this section, we focus on the relationship between the CYGNSS reflectivity and the large-scale roughness observed over different types of the Sahara environment. We discuss the influence of geometric roughness and the aerodynamic roughness length $Z_{0}$ on the signals received by CYGNSS. As SAR data are often used to map roughness in deserts and other regions of the globe, it is worthwhile to carefully compare the CYGNSS reflectivity results with SAR roughness measurements derived from ALOS-2 backscattering coefficients.

\subsection{Comparison between CYGNSS and ALOS-2 Data}

Prior to our analysis of the influence of roughness on CYGNSS $\Gamma$ data, the latter was compared with the ALOS-2 backscattering coefficient (or sigma nought: $\sigma_{0}$ ) data recorded over the regions described in Section 2.2. As shown in Figure 6, a linear relationship can be established between the ALOS-2 backscattering coefficient and the CYGNSS reflectivity. This comparison was carried out for the Kufrah area, where each point corresponds to a single $0.03^{\circ} \times 0.03^{\circ}$ pixel for both types of data $\left(\Gamma\right.$ and $\left.\sigma_{0}\right)$. A trend towards decreasing reflectivity, as a function of the increasing backscattering coefficient, can be seen in this figure. As it is known that in desert areas, variations of SAR data depend mainly on soil roughness, this relationship between the CYGNSS $\Gamma$ and SAR $\sigma_{0}$ data could potentially be used to retrieve surface roughness from CYGNSS observations. The relatively noisy correlation between CYGNSS $\Gamma$ and SAR $\sigma_{0}$ data is attributed mainly to the fact that incoherent SAR radar signals (ALOS-2 data) are compared with reflectivities that are associated to the coherent components of CYGNSS data. This means that different surface roughness properties are contributing to each of these remotely sensed parameters.

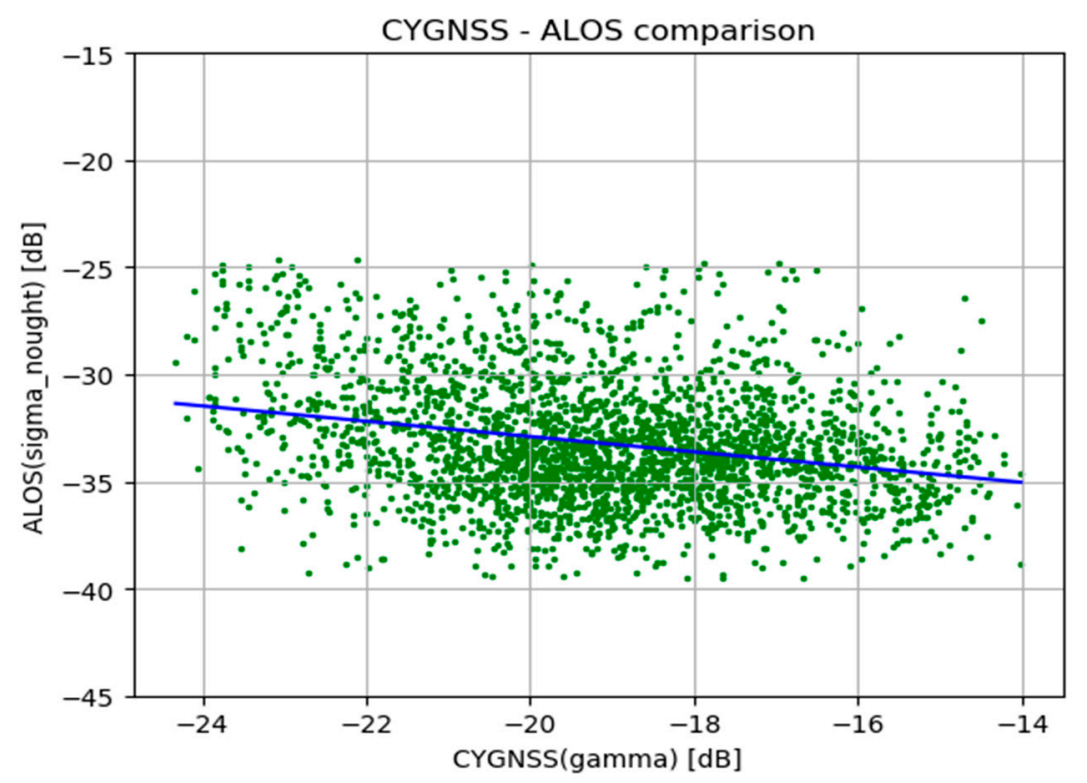

Figure 6. Plot of Advanced Land Observing Satellite-2 (ALOS-2) backscattering coefficient vs. CYGNSS reflectivity data collected over the Kufrah site, where each point corresponds to a pixel with a spatial resolution of $0.03^{\circ} \times 0.03^{\circ}$.

\subsection{Relationship between Geometric Roughness and CYGNSS T/ALOS-2 Sigma Naught Data}

In order to define large-scale roughness, mean slope values were considered in the same areas as those for which measurements of aerodynamic roughness of the terrain had been carried out (Table 1). Slope values were computed starting from the digital elevation model (DEM) of the SRTM mission, and the Horn algorithm was then used to compute the mean slope [49] from consecutive blocks of 
eight pixels. The mean slope values were then gridded onto maps with $0.03^{\circ} \times 0.03^{\circ}$ pixels in order to obtain the same resolution as that used for the CYGNSS and ALOS-2 data.

Figure 7 shows the mean values of CYGNSS $\Gamma$ and ALOS- $2 \sigma_{0}$ data corresponding to the $0.03^{\circ}$ pixels as a function of the mean slopes. An exponentially decreasing trend can be seen for the CYGNSS $\Gamma$ data as a function of increasing values of mean slope. Conversely, an empirical logarithmic increasing trend can be seen for the ALOS-2 backscattering coefficients as a function of increasing values of mean slope. At low values of slope, the corresponding values of CYGNSS $\Gamma$ and ALOS-2 data are strongly dispersed. This is probably due to the presence of different physical, micro-topographical contexts (flat rocky surfaces, sandy soils, etc.), which can significantly affect the coherent component of the CYGNSS signals and backscattered ALOS-2 data [50]. An increase in the strength of the incoherent component, as a function of roughness, could also lead to a certain degree of saturation of the CYGNSS reflectivity [37]. The correlation between roughness and the ALOS-2 data reveals a stronger degree of correlation at high levels of roughness, corresponding to areas with relief.

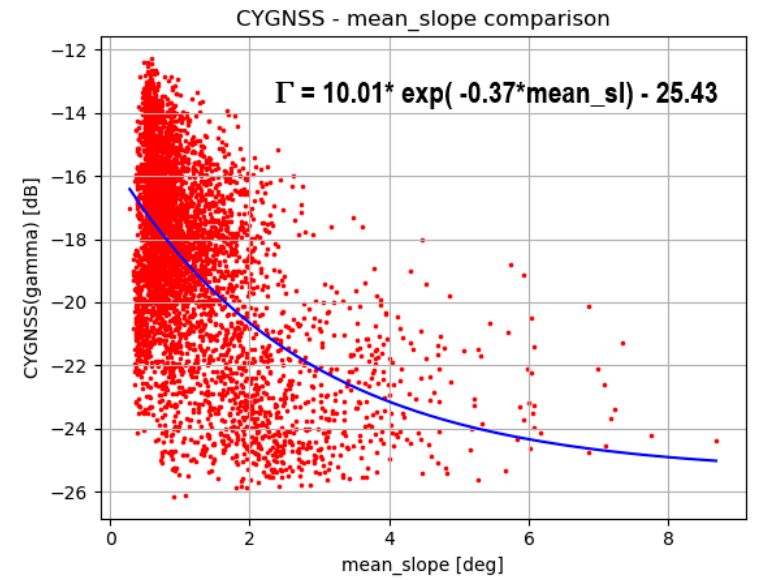

(a)

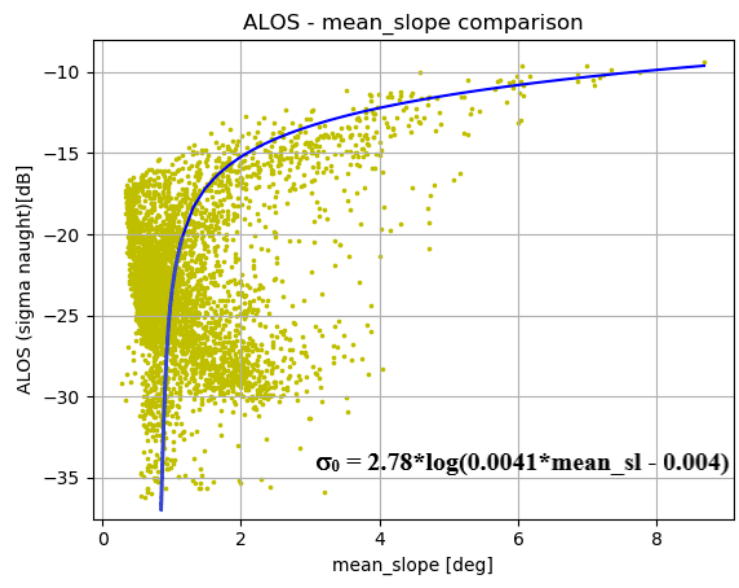

(b)

Figure 7. Plot of roughness mean slope and satellite data: (a) CYGNSS reflectivity, (b) ALOS-2 backscattering coefficient.

\subsection{Aerodynamic Roughness Length vs. CYGNSS/ALOS-2 Data}

Following the above analysis of the influence of geometric roughness, expressed in terms of the mean slope, this section discusses the influence of aerodynamic roughness. The analysis is based on the ground measurements illustrated in Table 1.

For each area with available ground measurements, the mean value of CYGNSS $\Gamma$ is computed. Figure 8 shows the empirical relationship between reflectivity $\Gamma$ and $Z_{0}$ for the ground measurement areas considered in Table 1. An approximately linear trend is found, with a correlation $R^{2}$ equal to 0.81 . The standard deviation of the reflectivity during the 2.5 years covered by this study is also shown, in order to appreciate the stability of the relationship.

The same procedure was applied to the ALOS-2 backscattering coefficients, taking into account the mean value of the backscattering coefficients inside the areas of interest. A linear trend is also found for this relationship $\left(R^{2}=0.63\right)$, which is very similar to that retrieved from ERS measurements [4]. In conclusion, the results of this study illustrate the relevance of CYGNSSS reflectivity measurements for the retrieval of aerodynamic roughness lengths in desert locations. 


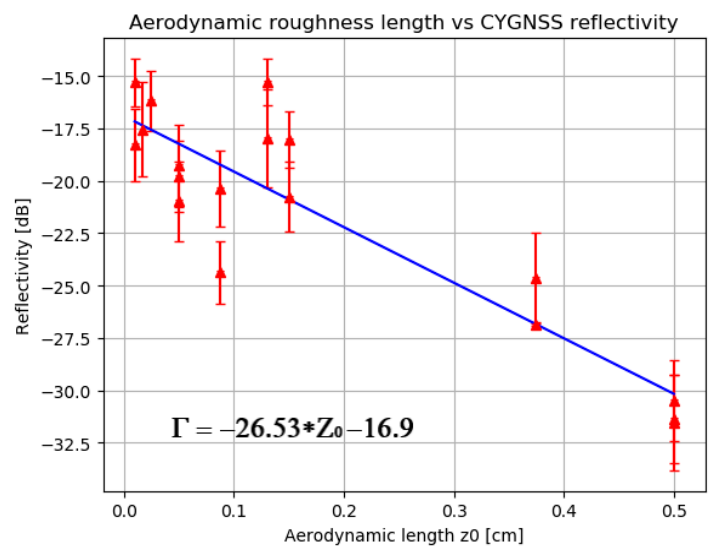

(a)

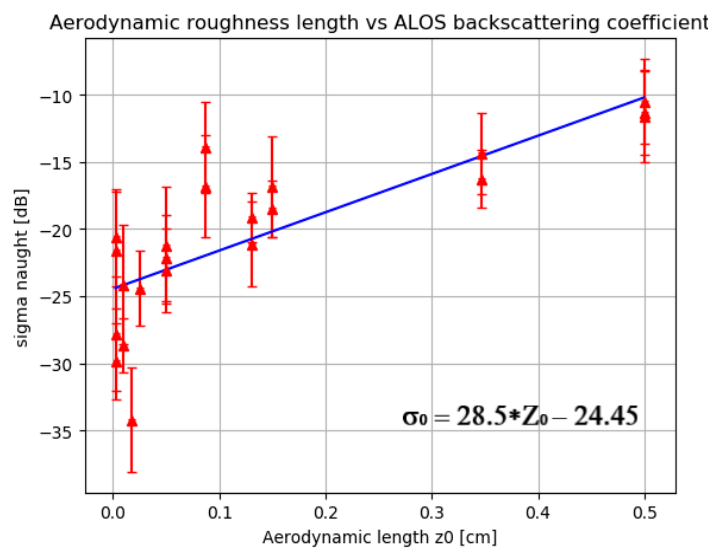

(b)

Figure 8. Plot of the aerodynamic roughness length as a function of satellite data: (a) CYGNSS reflectivity, (b) ALOS-2 backscattering coefficient.

\subsection{Aerodynamic Roughness Length Mapping}

On the basis of the empirical relationship developed in Section 4.3 the reflectivity is inverted in order to generate a map of aerodynamic roughness over the entire Sahara. As the accuracy of this relationship is moderate, four aerodynamic roughness classes are considered, as shown in Figure 9: the first class indicates comparatively smooth areas $\left(Z_{0}<0.1\right)$, corresponding to flat rocky surfaces; the second class, with $Z_{0}$ lying between 0.1 and 0.2 , indicates medium rough surfaces; the third class, with $Z_{0}$ lying between 0.2 and 0.3 , corresponds to rough rocks and hills; and finally, the highest roughness class, with $Z_{0}>0.3$, corresponds to non-masked mountainous areas. The map shown in Figure 9a was produced using an inversion of the empirical relationship in Figure 8a over a $10 \times 10$ pixel window to reduce local heterogeneities and retrieve the main structural features. It does not include the areas in the CYGNSS data that were filtered out, due either to their high altitudes or to the presence of dunes characterized by scattered signals with low SNR that were probably highly sensitive to subsurface features. The elimination of dunes was also considered in studies using data from the ERS scatterometer (Figure $9 \mathrm{~b}$ ). Despite the differences in the definition of roughness ranges for each class, maps derived from CYGNSS and from the ERS scatterometer [4] present significant similarities. With the ERS scatterometer, classes are particularly concentrated in very low $Z_{0}$ values.

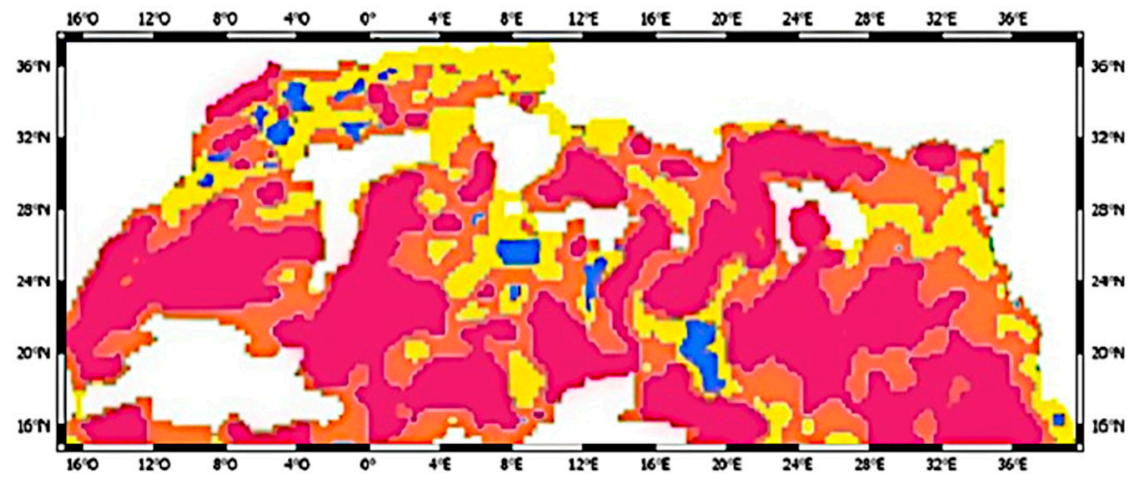

$\mathrm{ZO}>0.30 \mathrm{~cm}$

$0.20 \mathrm{~cm}<\mathrm{ZO}<0.30 \mathrm{~cm}$

$0.10 \mathrm{~cm}<\mathrm{Z} 0<0.20 \mathrm{~cm}$

$\mathrm{Z} 0<0.10 \mathrm{~cm}$

(a)

Figure 9. Cont. 


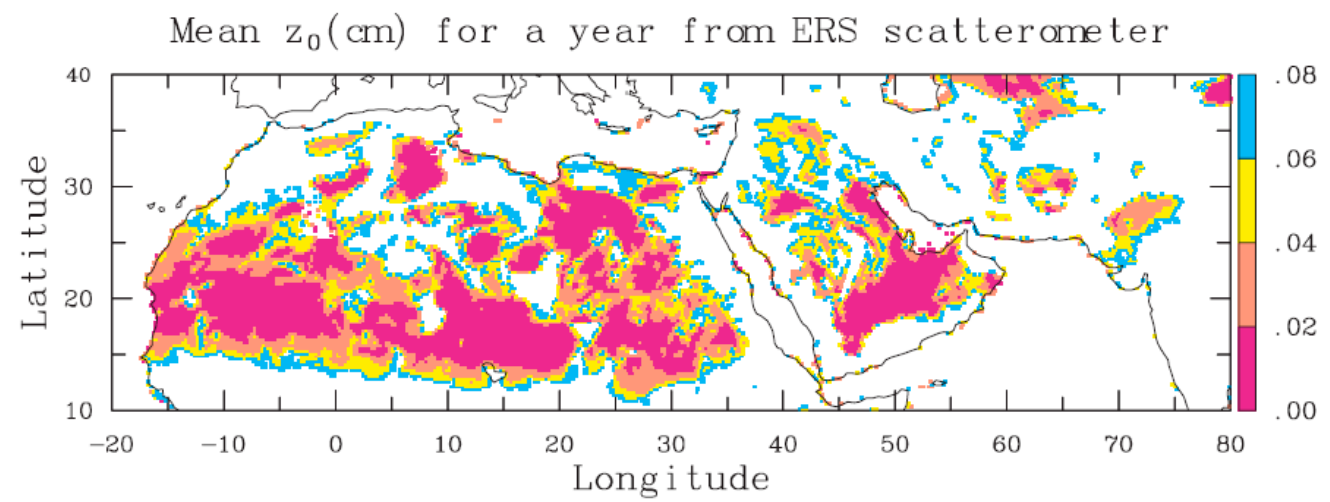

(b)

Figure 9. Maps of aerodynamic roughness classes over the Sahara desert: (a) derived from a CYGNSS reflectivity database, (b) derived from the European Remote-Sensing Satellite (ERS) scatterometer (Prigent et al. [4]).

\section{Conclusions}

GNSS-R data derived from CYGNSS observations have been used for the first time to characterize surface properties in a major desert area. This study demonstrates the strong stability of GNSS-R reflectivities $(\Gamma)$ in the Sahara desert, meaning that the long-term average of the reflectivity can be used to characterize surface properties. Thanks to this high stability, a grid could be produced to map the average reflectivity, with a fine resolution of $0.03^{\circ} \times 0.03^{\circ}$. The main structures of the dunes and reliefs are thus qualitatively observable. Our comparison of CYGNSS $\Gamma$ data and SAR ALOS-2/PALSAR $\sigma_{0}$ measurements reveals a robust correlation. The SAR radar signal is found to decrease with increasing reflectivity. This is directly related to roughness, with the main parameter affecting radar signal strength, in the absence of variations in soil water content. Using ground measurements of aerodynamic roughness or geometric roughness computed from the SRTM product, a relatively strong correlation is observed between the surface parameters and the reflectivity, with the correlation $\mathrm{R}^{2}$ equal to 0.81 for the aerodynamic roughness. From the resulting empirical relationship, a map of the Sahara showing four classes of aerodynamic roughness is proposed. These classes range from very smooth surfaces to mountainous surfaces corresponding to the highest values of roughness. This map strongly resembles the roughness products generated by scatterometer data. In the future, it would be of significant importance to gain a deeper understanding of the signals observed on the dunes, which remain difficult to interpret. This is probably due to the influence of sub-surface features and is not yet understood. It would also be important to validate the experimental observations with physical models, in order to reproduce the DDMs observed on each type of surface.

Author Contributions: M.Z. supervised and designed the methodologies; D.S. developed the algorithms; M.H. participated in the data processing, N.P. provided advice on CYGNSS data processing and methodologies; N.B. provided advice on results interpretation; D.S. and M.Z. wrote the paper. All authors have read and agreed to the published version of the manuscript.

Funding: This research was funded by CNES/TOSCA program.

Conflicts of Interest: The authors declare no conflict of interest.

\section{References}

1. Gillette, D.A.; Passi, R. Modeling dust emission caused by wind erosion. J. Geophys. Res. Space Phys. 1988, 93, 14233. [CrossRef]

2. Callot, Y.; Marticorena, B.; Bergametti, G. Geomorphological approach for modeling the surface features over arid environments in a model of dust emission: Application to the Sahara desert. Geodyn. Acta 2000, 13, 245-270. [CrossRef] 
3. Marticorena, B.; Kardous, M.; Bergametti, G.; Callot, Y.; Chazette, P.; Khatteli, H.; Le Hégarat-Mascle, S.; Maillé, M.; Rajot, J.; Vidal-Madjar, D.; et al. Surface and aerodynamic roughness in arid and semiarid areas and their relation to radar backscatter coefficient. J. Geophys. Res. Space Phys. 2006, 111. [CrossRef]

4. Prigent, C.; Tegen, I.; Aires, F.; Marticorena, B.; Zribi, M. Estimation of the aerodynamic roughness length in arid and semi-arid regions over the globe with the ERS scatterometer. J. Geophys. Res. Space Phys. 2005, 110, 12. [CrossRef]

5. Marticorena, B.; Aumont, B.; N’Doumé, C.; Bergametti, G.; Callot, Y.; Legrand, M. Modeling the atmospheric dust cycle: 2. Simulation of Saharan dust sources. J. Geophys. Res. Space Phys. 1997, 102, 4387-4404. [CrossRef]

6. Zribi, M.; Baghdadi, N.; Holah, N.; Fafin, O.; Guerin, C. Evaluation of a rough soil surface description with ASAR-ENVISAT radar data. Remote Sens. Environ. 2005, 95, 67-76. [CrossRef]

7. Le Hegarat-Mascle, S.; Zribi, M.; Ribous, L. Retrieval of elevation by radarclinometry in arid or semi-arid regions. Int. J. Remote Sens. 2005, 26, 2877-2899. [CrossRef]

8. Baghdadi, N.; Choker, M.; Zribi, M.; El Hajj, M.; Paloscia, S.; Verhoest, N.; Lievens, H.; Baup, F.; Mattia, F. A New Empirical Model for Radar Scattering from Bare Soil Surfaces. Remote Sens. 2016, 8, 920. [CrossRef]

9. Gorrab, A.; Zribi, M.; Baghdadi, N.; Mougenot, B.; Fanise, P.; Chabaane, Z.L. Retrieval of Both Soil Moisture and Texture Using TerraSAR-X Images. Remote Sens. 2015, 7, 10098-10116. [CrossRef]

10. Baghdadi, N.; Grandjean, G.; Lahondère, D.; Paillou, P.; Lasne, Y. Apport de l'imagerie satellitaire radar pour l'exploration géologique en zones arides. Comptes Rendus Geosci. 2005, 337, 719-728. [CrossRef]

11. Grandjean, G.; Paillou, P.; Baghdadi, N. A Volume Scattering Model for Coupled Interpretation of Ground-Penetrating Radar (GPR) and Synthetic Aperture Radar (SAR). Subsurf. Sens. Technol. Appl. 2004, 5, 151-164. [CrossRef]

12. Paillou, P.; Grandjean, G.; Baghdadi, N.; Heggy, E.; August-Bernex, T.; Achache, J. Subsurface imaging in south-central egypt using low-frequency radar: bir safsaf revisited. IEEE Trans. Geosci. Remote Sens. 2003, 41, 1672-1684. [CrossRef]

13. Martin-Neira, M. A Passive Reflectometry and Interferometry System(PARIS)- Application to ocean altimetry. ESA J. 1993, 17, 331-355.

14. Zavorotny, V.U.; Gleason, S.; Cardellach, E.; Camps, A. Tutorial on Remote Sensing Using GNSS Bistatic Radar of Opportunity. IEEE Geosci. Remote Sens. Mag. 2014, 2, 8-45. [CrossRef]

15. Li, W.; Cardellach, E.; Fabra, F.; Rius, A.; Ribó, S.; Martín-Neira, M. First spaceborne phase altimetry over sea ice using TechDemoSat-1 GNSS-R signals. Geophys. Res. Lett. 2017, 44, 8369-8376. [CrossRef]

16. Rius, A.; Cardellach, E.; Fabra, F.; Li, W.; Ribó, S.; Hernández-Pajares, M. Feasibility of GNSS-R Ice Sheet Altimetry in Greenland Using TDS-1. Remote Sens. 2017, 9, 742. [CrossRef]

17. Li, W.; Cardellach, E.; Fabra, F.; Ribó, S.; Rius, A. Measuring Greenland Ice Sheet Melt Using Spaceborne GNSS Reflectometry from TechDemoSat-1. Geophys. Res. Lett. 2020, 47. [CrossRef]

18. Masters, D. Initial results of land-reflected GPS bistatic radar measurements in SMEX02. Remote Sens. Environ. 2004, 92, 507-520. [CrossRef]

19. Katzberg, S.J.; Torres, O.; Grant, M.S.; Masters, D. Utilizing calibrated GPS reflected signals to estimate soil reflectivity and dielectric constant: Results from SMEX02. Remote Sens. Environ. 2006, 100, 17-28. [CrossRef]

20. Rodriguez-Alvarez, N.; Bosch-Lluis, X.; Camps, A.; Vall-Llossera, M.; Valencia, E.; Marchan-Hernandez, J.; Ramos-Perez, I. Soil Moisture Retrieval Using GNSS-R Techniques: Experimental Results Over a Bare Soil Field. IEEE Trans. Geosci. Remote Sens. 2009, 47, 3616-3624. [CrossRef]

21. Egido, A.; Caparrini, M.; Ruffini, G.; Paloscia, S.; Santi, E.; Guerriero, L.; Pierdicca, N.; Floury, N. Global Navigation Satellite Systems Reflectometry as a Remote Sensing Tool for Agriculture. Remote Sens. 2012, 4 , 2356-2372. [CrossRef]

22. Egido, A.; Paloscia, S.; Motte, E.; Guerriero, L.; Pierdicca, N.; Caparrini, M.; Santi, E.; Fontanelli, G.; Floury, N. Airborne GNSS-R Polarimetric Measurements for Soil Moisture and Above-Ground Biomass Estimation. IEEE J. Sel. Top. Appl. Earth Obs. Remote Sens. 2014, 7, 1522-1532. [CrossRef]

23. Pei, Y.; Notarpietro, R.; Savi, P.; Cucca, M.; and Dovis, F. A Fully Software GNSS-R receiver for Soil Monitoring. Int. J. Remote Sens. 2014, 35, 2378-2391. [CrossRef]

24. Sanchez, N.; Arroyo, A.A.; Martínez-Fernández, J.; Piles, M.; González-Zamora, Á.; Camps, A.; Vall-Llossera, M. On the Synergy of Airborne GNSS-R and Landsat 8 for Soil Moisture Estimation. Remote Sens. 2015, 7, 9954-9974. [CrossRef] 
25. Jia, Y.; Savi, P.; Canone, D.; Notarpietro, R. Estimation of Surface Characteristics Using GNSS LH-Reflected Signals: Land Versus Water. IEEE J. Sel. Top. Appl. Earth Obs. Remote Sens. 2016, 9, 4752-4758. [CrossRef]

26. Zribi, M.; Pardé, M.; Boutin, J.; Fanise, P.; Hauser, D.; Dechambre, M.; Kerr, Y.H.; Leduc-Leballeur, M.; Reverdin, G.; Skou, N.; et al. CAROLS: A New Airborne L-Band Radiometer for Ocean Surface and Land Observations. Sensors 2011, 11, 719-742. [CrossRef]

27. Motte, E.; Zribi, M.; Fanise, P.; Egido, A.; Darrozes, J.; Al-Yaari, A.; Baghdadi, N.; Baup, F.; Dayau, S.; Fieuzal, R.; et al. GLORI: A GNSS-R Dual Polarization Airborne Instrument for Land Surface Monitoring. Sensors 2016, 16, 732. [CrossRef]

28. Camps, A.; Park, H.; Pablos, M.; Foti, G.; Gommenginger, C.; Liu, P.-W.; Judge, J. Sensitivity of GNSS-R Spaceborne Observations to Soil Moisture and Vegetation. IEEE J. Sel. Top. Appl. Earth Obs. Remote Sens. 2016, 9, 4730-4742. [CrossRef]

29. Chew, C.; Shah, R.; Zuffada, C.; Hajj, G.; Masters, D.; Mannucci, A.J. Demonstrating soil moisture remote sensing with observations from the UK TechDemoSat-1 satellite mission. Geophys. Res. Lett. 2016, 43, 3317-3324. [CrossRef]

30. Jia, Y.; Savi, P. Sensing soil moisture and vegetation using GNSS-R polarimetric measurement. Adv. Space Res. 2017, 59, 858-869. [CrossRef]

31. Carreno-Luengo, H.; Lowe, S.; Zuffada, C.; Esterhuizen, S.; Oveisgharan, S. Spaceborne GNSS-R from the SMAP Mission: First Assessment of Polarimetric Scatterometry over Land and Cryosphere. Remote Sens. 2017, 9, 362. [CrossRef]

32. Zribi, M.; Motte, E.; Baghdadi, N.; Baup, F.; Dayau, S.; Fanise, P.; Guyon, D.; Huc, M.; Wigneron, J.-P. Potential Applications of GNSS-R Observations over Agricultural Areas: Results from the GLORI Airborne Campaign. Remote Sens. 2018, 10, 1245. [CrossRef]

33. Camps, A.; Vall-llossera, M.; Park, H.; Portal, G.; Rossato, L. Sensitivity of TDS-1 GNSS-R Reflectivity to Soil Moisture: Global and Regional Differences and Impact of Different Spatial Scales. Remote Sens. 2018, 10, 1856. [CrossRef]

34. Chew, C.C.; Small, E. Soil Moisture Sensing Using Spaceborne GNSS Reflections: Comparison of CYGNSS Reflectivity to SMAP Soil Moisture. Geophys. Res. Lett. 2018, 45, 4049-4057. [CrossRef]

35. Clarizia, M.P.; Pierdicca, N.; Costantini, F.; Floury, N. Analysis of CYGNSS Data for Soil Moisture Retrieval. IEEE J. Sel. Top. Appl. Earth Obs. Remote Sens. 2019, 12, 2227-2235. [CrossRef]

36. Wan, W.; Liu, B.; Zeng, Z.; Chen, X.; Wu, G.; Xu, L.; Chen, X.; Hong, Y. Using CYGNSS Data to Monitor China's Flood Inundation during Typhoon and Extreme Precipitation Events in 2017. Remote Sens. 2019, 11, 854. [CrossRef]

37. Al-Khaldi, M.M.; Johnson, J.T.; O’Brien, A.J.; Balenzano, A.; Mattia, F. Time-Series Retrieval of Soil Moisture Using CYGNSS. IEEE Trans. Geosci. Remote Sens. 2019, 57, 4322-4331. [CrossRef]

38. Calabia, A.; Molina, I.; Jin, S. Soil Moisture Content from GNSS Reflectometry Using Dielectric Permittivity from Fresnel Reflection Coefficients. Remote Sens. 2020, 12, 122. [CrossRef]

39. Pierdicca, N.; Guerriero, L.; Giusto, R.; Brogioni, M.; Egido, A. SAVERS: A Simulator of GNSS Reflections from Bare and Vegetated Soils. IEEE Trans. Geosci. Remote Sens. 2014, 52, 6542-6554. [CrossRef]

40. Ruf, C.S.; Atlas, R.; Chang, P.S.; Clarizia, M.P.; Garrison, J.L.; Gleason, S.; Katzberg, S.J.; Jelenak, Z.; Johnson, J.T.; Majumdar, S.J.; et al. New Ocean Winds Satellite Mission to Probe Hurricanes and Tropical Convection. Bull. Am. Meteorol. Soc. 2016, 97, 385-395. [CrossRef]

41. Gleason, S. Level 1B DDM Calibration Algorithm Theoretical Basis Document, CYGNSS Project Document 148-0137-X1, Rev1. December 2014. Available online: http://clasp-research.engin.umich.edu/missions/ cygnss/reference/ATBD\%20L1B\%20DDM\%20Calibration\%20R1.pdf (accessed on 23 February 2020).

42. Gleason, S.; Ruf, C.S.; O’Brien, A.J.; McKague, D.S.; OrBrien, A.J. The CYGNSS Level 1 Calibration Algorithm and Error Analysis Based on On-Orbit Measurements. IEEE J. Sel. Top. Appl. Earth Obs. Remote Sens. 2019, 12, 37-49. [CrossRef]

43. Balakhder, A.M.; Al-Khaldi, M.M.; Johnson, J.T. On the Coherency of Ocean and Land Surface Specular Scattering for GNSS-R and Signals of Opportunity Systems. IEEE Trans. Geosci. Remote Sens. 2019, 57, 10426-10436. [CrossRef]

44. Camps, A. Spatial Resolution in GNSS-R Under Coherent Scattering. IEEE Geosci. Remote Sens. Lett. 2020, 17, 32-36. [CrossRef] 
45. Ruf, C.S. DDM Data Compression and Decimation Algorithm, SPRL Tech. Memorandum 148-0046-X1. May 2013.

46. Eorc. Jaxa. “Alos Data Users Handbook" Tokyo. March 2008. Available online: https://www.eorc.jaxa.jp/ ALOS/en/doc/fdata/ALOS_HB_RevC_EN.pdf (accessed on 22 February 2020).

47. Shimada, M.; Itoh, N.; Watanabe, M.; Moriyama, T.; Tadono, T. PALSAR initial calibration and validation results. Sens. Syst. Next-Gener. Satell. X 2006, 6361, 636103.

48. Cook, K.H.; Vizy, E.K. Contemporary Climate Change of the African Monsoon Systems. Curr. Clim. Chang. Rep. 2019, 5, 145-159. [CrossRef]

49. Horn, B. Hill shading and the reflectance map. Proc. IEEE 1981, 69, 14-47. [CrossRef]

50. Zribi, M.; Gorrab, A.; Baghdadi, N. A new soil roughness parameter for the modelling of radar backscattering over bare soil. Remote Sens. Environ. 2014, 152, 62-73. [CrossRef]

(C) 2020 by the authors. Licensee MDPI, Basel, Switzerland. This article is an open access article distributed under the terms and conditions of the Creative Commons Attribution (CC BY) license (http://creativecommons.org/licenses/by/4.0/). 